\title{
Research on the reform of county-level Fangguanfu in ethnic regions in China - a case study of the Fangguanfu Reformation at Ongniud Banner
}

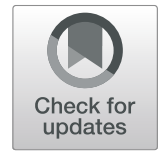

\author{
Yong Fang $\cdot$ Jinghong Zhou $\cdot$ Shaochun Zhang $\cdot$ WuRigexiletu $\cdot$ Lei Shao $\cdot$ Xin Liang
}

Received: 8 May 2020 /Accepted: 3 July 2020 / Published online: 29 July 2020

(C) The Author(s). 2020 Open Access This article is licensed under a Creative Commons Attribution 4.0 International License, which permits use, sharing, adaptation, distribution and reproduction in any medium or format, as long as you give appropriate credit to the original author(s) and the source, provide a link to the Creative Commons licence, and indicate if changes were made. The images or other third party material in this article are included in the article's Creative Commons licence, unless indicated otherwise in a credit line to the material. If material is not included in the article's Creative Commons licence and your intended use is not permitted by statutory regulation or exceeds the permitted use, you will need to obtain permission directly from the copyright holder. To view a copy of this licence, visit http://creativecommons.org/licenses/by/4.0/.

\begin{abstract}
Ongniud Banner, as a mixed agricultural and pastoral county-level administrative region within the Inner Mongolia Autonomous Region, actively promotes an improved level of government services, especially the Fangguanfu Reform promoted by the central government of China. The banner government actively sought to overcome difficulties related to the foundation, technical conditions, and institutional constraints, and thus solidly promoted the Fangguanfu Reform in the county, achieving significant results in "decentralization", increased awareness of "supervision", and "service". The initial creation of the service system and the positive impact of significantly improved efficiency have enabled government services to increasingly reflect the political concept of governing for the people, effectively optimizing the environment for local development.
\end{abstract}

Fangguanfu, 放管服, to streamline government functions and administration, delegate powers while improving regulation, reinforce supervision, and optimize services.

Y. Fang $(\bowtie) \cdot$ J. Zhou $\cdot$ S. Zhang $\cdot$ WuRigexiletu $\cdot$ L. Shao

The Institute of Ethnology and Anthropology, Chinese Academy of Social Sciences, Room332, Chengming Building, Xizhimen Street No.2, Xicheng District, Beijing, China e-mail: fangyong@ cass.org.cn

X. Liang

College of Ethnology and Sociology of Guangxi University for Nationalities, No.188, East University

Road, Nanning 530006, Guangxi, China 
Keywords County level of an ethnic region · Fangguanfu Reform · Ongniud Banner The reform of the administrative system in China

Since the reform and opening-up, the Chinese government has conducted administrative reforms. In 2013, the "State Council Mechanism Reform and Function Transformation Program" formed the seventh reform of government agencies and promoted a new round of the transformation of government functions to better manage the relationship between the government and the market. Its relationship with society has required the government to decentralize its power and management. During this time, reforms to simplify and decentralize administration, to combine decentralization with management, and to optimize services have started. In 2015, research on "Fangguanfu" was first published in domestic journals, mainly in professional journals about simplified government, decentralization reforms, construction of the Administration Rule of Law, administrative management reform, and business administration and management. In 2016, the relevant research was broadened and the lessons from local government reforms have been actively discussed. Since that time, hundreds of related journal papers have been published, focusing on, among other topics, the business environment, and the use of the internet in government services. Since 2017, research results of relevant works have been published, such as "Third-Party Evaluation of 'Fangguanfu' in Qinghai Province "(The third party evaluation project team, 2017), "Sanxiang Fangguanfu" (Wei Xuanjun, 2017), "Fangguanfu“ by your side" (The Office of the Coordination Group, 2017)". The present work studies the Fangguanfu Reform in a mixed agricultural and pastoral county area of Inner Mongolia, observing the historical process of the local administrative reform, the change of the power list between superiors and subordinates in the process of the upgrading of government affairs service, and the benefit and convenience that the upgrade of government services has brought to the life of farmers and herdsmen.

The reform of the governmental administrative system has been an important part of Chinese social reform. During the reforms and opening up of the last 40 years, reforms within the administrative system of the Chinese government have been continuously promoted for exploration. Important targets of this reform have been the transformation of governmental functions as well as an active investigation into the relationships between both the government and the market and the government and society, in order to adapt to the new environment and respond to new societal demands, to let the market play a definitive role in resource allocation, as well as improving the role of the government. As a part of the process of transforming governmental functions, the focus of governmental effort is to create an environment that fosters development, to provide high quality public services, and to maintain a fair and just society. Therefore, recent years we have seen the Fangguanfu Reform making continuous progress, having the transformation of government function as the essential core, and the reform of the administrative system as breakthroughs and handholds. The Fangguanfu Reform summarized the streamline administration, delegate powers, and improve regulation and services by the higher-level government, reflecting a deeper understanding of the principle of governing for the people. Local governments at every level conducted 
investigations based on the reform objective, constructed an information platform, decentralized services, consolidated government authority, and created a convenient service platform. In 2012, the level of government service in Ongniud Banner has been continuously upgraded. The reform of administrative system focused on fangguanfu has been consistently promoted. The effect of "delegating power" has been remarkable, the awareness of "supervision" has been strengthened, and the "service" system has taken its initial shape. The efficiency of public services has been significantly improved, creating a unique experience of and mode for Fangguanfu Reform in the ethnic areas at the county level, especially in those stricken by poverty. Ongniud Banner, as a poor county in an ethnic region, had an undeveloped infrastructure and weak economic strength. However, inspired by the reform goals, the departments of the banner government actively seized upon this opportunity for reform, obtaining preliminary results marked by local characteristics in the Fangguanfu Reform. Premier Li Keqiang visited Ongniud Banner twice to investigate and fully affirmed the Fangguanfu Reform in this region.

\section{Background: economic and social profile of Ongniud Banner}

Ongniud Banner is one of the thirty-three traditional animal husbandry banners of the Inner Mongolia Autonomous Region. It is located in the central part of Chifeng City, with a total administrative area of $11,882 \mathrm{~km}^{2}$. The banner government oversees eight towns, four towns, two townships, two sub-district offices, six state-run farms, 229 administrative villages, and eight resident committees. At the end of 2017 , the total registered population surpassed 480,000. In terms of the urban and rural distribution of household registrations, around $76 \%$ of the population remains rural, but the rural population has shifted on a considerable scale to urban areas. The ethnic composition of the whole banner population has an absolute majority of Han people, forming $82 \%$ of the population, with a sizeable ethnic minority of Mongolians, in addition to Manchus, Hui, and ethnic Korean minorities. The region has a rich historical and cultural heritage, with cave sites dating to the Paleolithic era, Hongshan cultural sites of the Neolithic Age, and Xiajiadian cultural sites from the Bronze Age. With this rich historical and cultural heritage, Ongniud Banner has the reputation of "the hometown of dragons and phoenixes".

At the early years of reform and opening-up, Ongniud Banner was in the initial group of 258 poverty counties of national level found throughout China. Ongniud was the primary focus for support by the Party Central Committee, the State Council, the Inner Mongolia Autonomous Region and other governments at every level. More than 40 years of hard work has tremendously changed the economic and social outlook of the whole banner; building upon this foundation, Ongniud Banner is committed to a targeted poverty alleviation, in order to be free of its nationally-appointed title as a poverty-stricken county. With the continually deepening reform and increased openness, the status of the economic and social development of the banner area has risen year after year. The overall economic strength of the whole banner has been fortified, the economic infrastructure has been continuously improved and diversified, and this transformation has changed 
the fiscal condition from "fragile" to "strong". The amount of protection given to infrastructure, as well as the living status of the residents, is constantly improving. According to the results of the research team's questionnaire, ${ }^{1}$ residents give a high evaluation of the economic and social development of the banner during these 40 years. In excess of $90 \%$ of the respondents are confident that the region will no longer have the poverty-stricken label at the end of 2018 and will instead realize a moderately prosperous society by 2020 .

\section{Methodology and data sources}

The main methods utilized in this study are field research and questionnaire interviews. In June 2018, six scholars from the Institute of Ethnology and Anthropology of the Chinese Academy of Social Sciences and Guangxi University for Nationalities formed a research team that went to Ongniud Banner for 17 days. During the investigation, the team held discussions with thirty-five relevant committees of the banner government, interviewed fifteen leaders and merchants of relevant units, visited five townships and five village agencies, and received responses to electronic questionnaires. During its time in the banner, the research team launched an electronic questionnaire, which was clicked more than 700 times and yielded 201 valid answer sets. The data used in the study, except when specially noted, are derived from the primary data of the field investigation of the research team.

\section{Discussion: research and analysis on the Fangguanfu reform of the Ongniud Banner}

The historical transformation of banner government functions and the source of its power

The county-level government wields the dual functions of grassroots political power and administrative institutions; the daily administration of the county-level government must implement decisions passed down both from a higher level and from its own administrative level, while assuming full responsibility for the county's economic and social development. The reform and opening-up triggered a reform of the administrative system, including the transformation of government functions, the adjustment of administrative institutions, a change in management methods, the reform of the government's system of administrative leadership, the reform of the civil service system, the reform of the government management system, and the reform of administrative office methodologies. According to the

\footnotetext{
${ }^{1}$ During the investigation in the banner, the research team launched an electronic questionnaire that was accessed more than 700 times and that provided 201 valid answer sets. $63.68 \%$ of the respondents who answered the questionnaire were cadres, $9.95 \%$ were workers, $4.48 \%$ were farmers, and $21.89 \%$ were other. Among them, $88.56 \%$ of the respondents were resident in the banner and $11.44 \%$ did not live in the banner.
} 
overall process of the reform of the state administrative system, and based on the top-down characteristic driving this county-level reform of administrative systems, the reform of the administrative system reform of Ongniud Banner went through two historical stages.

\section{The phase of administrative reform centered on institutional streamlining (1983-1991)}

The reform of the administrative system during this period, from the perspective of the modes of promotion and goals of the State Council, concerned the adjustment of the organization and the constitution of the civil servants. Therefore, the main content of the Ongniud Banner reform altered the number of banner government institutions and changed their management style. Additionally, the changes involved the reform of the civil service mechanism and the establishment of a grassroots political structure through the cancellation of the commune system and the establishment of townships (Sumu). In June 1981, the Revolutionary Committee of Ongniud Banner was abolished and the people's government system was restored. The county-level administrative agencies were primarily composed of the system of commissions, offices, and bureaus. After these changes of adjustment, mergers and joint in 1985, the agencies of the Ongniud Banner government were reduced from fifty-three administrative agencies to thirty-five departments. In 1988, the First Session of the Seventh National People's Congress established the overall goal of institutional reform: to establish a system of administrative management that had modern functions, complete functionality, a reasonable structure, coordinated operations, flexibility, and efficiency, and that promoted the development of productive social forces, and consolidated the people's democratic power. As a result, the goals of the reform of county-level administrative organizations have become increasingly clear: to transform their functions, to rationalize their relationships, to streamline their institutions, to streamline their personnel, to revitalize their institutions, and to improve their administrative efficiency.

\section{The phase of market economic system transformation and administrative system reform (1992 to present)}

In 1992, after determining whether the economy should be labeled according to "capitalism" or "socialism", 2 the transformation of the market led to new requirements concerning administrative efficiency, governmental efficiency, and management methodologies of governments at every level. The reform of the administrative system of the government grew in urgency. The State Council proposed that "if the county economy is basically market-regulated, then the reform can take bigger steps." The agencies of the county government employ the reform principle of "small institutions and large services". The State Council created

\footnotetext{
${ }^{2}$ That is to say, in the process of China's socialist construction, we can learn from the achievements of capitalist system to build a socialist market economy under certain conditions. The socialist market economic system is an economic system that makes the market mechanism play a fundamental role in the allocation of social resources on the basis of socialist public ownership and under the state's macrocontrol.
} 
specific standards for all institutions and organizations, and the professional economic departments changed into economic or human services entities. Their administrative functions were concentrated under the comprehensive management of the government. The human service personnel stationed in the townships and towns were directly sent by the county departments, such as the departments of agricultural machinery, agricultural technology, animal husbandry, veterinary, culture, or broadcasting. These were managed by the township governments, while some more professional institutions and their personnel were led by both townships and the relevant departments, being mainly led by township management. Institutions and personnel which supervise and inspect, such as with regards to industry, commerce, or taxation, were led by both townships and the relevant departments, being mainly led by the relevant department. ${ }^{3}$ The relationship between the government and businesses was adjusted, and the allocation of power in the county adapted to the market economy mode and its requirements for efficiency and effectiveness. As a second-class county, Ongniud Banner had about twenty-five standard institutions and 650 staff. In accordance with the unified deployment of the autonomous region, in 1993, Ongniud Banner reformed the party and governmental institutions by merging ten party and government departments with overlapping institutions and similar functions, changing the human service functions of the five administrative organs into institutions, and transforming the two administrative and economic departments into enterprises. The comprehensive reforms have since been reformed, from simply reducing people and merging institutions, and are instead now being centered on developing urban and rural economic centers, and transforming functions and strengthening efficiency.

In the twenty-first century, the reform of the governmental administrative system, in adjusting the institutions' efficiency, promotes the opening of government business to public and government services, further improving the relationship between the government and enterprise, and between the market and society by the reform of the administrative power to inspect and approve. In June 2000, Inner Mongolia promoted the simplification of administrative inspection and approval of businesses, ${ }^{4}$ and the autonomous regional government required all localities and working departments to further transform their governmental functions. According to the requirements of the socialist market system and the establishment of a modern enterprise system, they carefully cleaned up elements concerning administrative inspection and approval, and canceled or decentralized a number of the steps for approval as well. Specific actions taken include narrowing the scope of administrative inspection and approval, simplifying the relevant procedures, establishing a public notification system, limiting the time limit for inspection and approval, strictly controlling inspections, standardizing the inspection and approval of enterprises, and establishing a sound system for reporting.

\footnotetext{
3"Regulations on the Reform of Party and Government Organizations", in the "Handbook for the Discipline Inspection and Supervision of Cadres", China Fangzheng Press, 2002, p. 189.

4 "Notice of the People's Government of Inner Mongolia Autonomous Region on Further Simplifying the Administrative Examination and Approval and Inspection of Enterprises" (Internal Affairs [2000] No. 67).
} 
The various problems of the administrative management in the autonomous region were targeted, such as "multiple procedures, complicated procedures, low efficiency, difficulty in reaching solutions", irregular approval items, inadequate legal support, an unsound mechanism of supervision, lack of necessary supervision and approval for inspection and approval actions, and difficulty to investigate the approval responsibilities. In December 2000, the government of the autonomous region issued the "Notice on the streamlining of government functions, the delegation of powers, and the opening of the administration to the public" (Inner Affairs [2000] No. 132), requiring further streamlining of government functions, increasing of the delegation of power, and the standardizing of government administration. The autonomous regional government established a task force aimed at the reform of the administrative inspection and approval system in order to implement the task of reforming the administrative system as given by the Party Central Committee and the State Council, and to promote the reform of the administrative service of Ongniud Banner.

In October 2001, the State Council approved the Ministry of Supervision, the State Council Legislative Affairs Office, the State Council Reform Office and the Central Organizing Office to jointly issue the "Opinions on the Implementation of the Reform of the Administrative Approval System" (State Affairs [2001] No. 33), which requires strict cancellation of administrative approval that does not conform with the principles of the separation of government and business, the separation of government affairs, and that would hinder the openness and fair competition of the market. This opinion also abolishes administrative approval that could be replaced by a mechanism that operates through the market. For any administrative inspection and approval that is to continue, a fully functional supervision and control procedure must be established, so that the inspection and approval procedures are strict, the number of inspection and approval procedures is reduced, the inspection and approval efficiency is improved, and the relevant accountability system is strictly enforced. At the end of 2001, the autonomous region examined the reform of the administrative inspection and approval system in various cities and counties and further promoted the pace of reform of these administrative services of Ongniud Banner.

In summary, following reform and opening-up, the reform of the administrative system promoted by the Party Central Committee and the State Council changed from adding or reducing institutions into the reform of institutional functions, especially adapting to meet the needs created by the transformation of the economy system, the exploration of reform paths and methods in disclosing government affairs and government services, and the formation of a strong driving force for the reform of county-level government affairs.

\section{Evaluation of the effect of reform}

As a county-level government, Ongniud Banner, primarily in accordance with the decision-making arrangements of the State Council, the autonomous region and Chifeng City in combination with the banner-specific conditions, actively implemented the relevant requirements for strengthening the reform of the administrative 
system, promoting the upgrade of government services, promoting the upgrade of administrative approval in the banner area, and reforming the quality of government service.

\section{Absorb functions effectively}

As a county level government, the process of fangguanfu at Ongniud Banner is a process of following up. More precisely, it is a process of implementing and carrying out the reforming task and goals given from above. In accordance with the reform requirements of the autonomous region and municipal services, the various departments of the Ongniud Banner Government earnestly worked to decentralize higher-level projects, formulate the inspection and approval plans for the project, comprehensively implement the specific departments, handle the process in a clear manner, accomplish the work according to the law, and follow orderly specifications to avoid a management "vacuum". Within this process, a working department of the banner government authorizes an approval for decentralization to a specific contractor's office and the relevant responsible persons, and trains the specific executive personnel according to the actual situation, effectively ensuring the orderly undertaking and efficient operation of decentralized concerns. From 2002 to 2016, Ongniud Banner undertook 201 administrative approval items as given from an upper level. In 2013, these projects were reviewed by the development and reform departments of the autonomous region, the city, and the county, which found that the number of projects approved by Banner County was more than half, and the investment approved by the city was two-thirds. In 2016, the State Council, the autonomous region and Chifeng City decentralized 187 tasks to the county, more specifically to the twenty-seven departments of the banner government. The largest number of decentralized tasks, twenty-two, was given to the tax bureaus; the Civil Affairs Bureau, the Grain Bureau, the Civil Defense Office, the Disabled Persons' Federation, and the County People's Government each only received one task. Departments that received more than 10 but less than 20 were the Public Security Bureau, the Culture and Broadcasting Bureau, the Market Supervision Bureau, the Health Planning Bureau, the Transportation Bureau, the Water Resources Bureau, and the Housing and Construction Bureau.

\section{Effectively implement the administrative licensing law and optimize the environment for development}

In 2008, the banner government office issued the "Regulations on Further Optimizing the Development Environment", requiring all government departments to create "five environments" through their respective work. Optimizing the environment of development has been implanted into the grass-roots party committee, the banner

\footnotetext{
${ }_{5}^{5}$ Preferential and mutually beneficial policy environment, fair and strict rule of law environment, civilized and high-quality service environment, standardized and orderly market environment, and honest and trustworthy credit environment.
} 
government, the annual assessment of grass-roots party committee, and the banner departments. The banner government requires that the administrative licenses and non-permitted inspection and approval items be continuously cleaned up in accordance with the provisions of the Administrative Licensing Law, and that they be implemented after public notices were placed on government websites, newspapers and periodicals. In order to protect policy goals, there are a series of related system guarantees, including the increased or decreased reporting system about administrative licensing, the approval and publication system, the pre-trial system for joint meetings before the implementation of a project, the charging and certification of fees, the strict regulation of administrative punishments, the standardization of the approval process, the strict regulation of the services and the charges of an agency.

\section{Promote the construction of the government center}

The Ongniud Banner Government Service Center was established in 2004 and officially opened in 2006. The service hall of the Administrative Service Center covers an area of 1300 square meters. It is divided into the convenience service center and the enterprise-related service center. It primarily deals with the organization, coordination, supervision and management of the administrative inspection and approval system for the whole banner. The Administrative Service Center initially consisted of a comprehensive management office and a head office for the resident leaders, which serves as a banner government office. There are six managers and sixty-eight customer service representatives in the service center. At that time, nineteen government departments were stationed in the service center, as well as ninety-six administrative approval services, 180 charging services, and fourteen windows. In 2016, the Administrative Center set up a comprehensive acceptance window to provide consultations for applicants, assist in filling out various forms and other services, provide services after initial examination, improve the quality of form filling, decrease the time it took for people to fill out forms, and improve the efficiency of window materials reviewing.

\section{Strengthen the supervision of government services}

In 2009, in order to support the construction of an electronic supervision system for administrative approval within the whole banner, the banner inspection committee and the banner administrative inspection and approval service center reorganized the administrative licensing items in the thirty-nine units throughout the whole banner. The work was mostly completed in August of that year. Based on the law, they kept 129 items and forty-six non-administrative licensing approval items while removing four administrative licenses and eleven non-administrative licenses. In September 2010, the Ongniud Banner Administrative Approval Service Center purchased electronic inspection software for administrative approval to strengthen their electronic supervision, supplied by Chifeng Juan Technology Trading Co., Ltd. at a cost of more than 440,000 Chinese dollars. 


\section{Conduct a pilot project for open government affairs}

In November 2011, Ongniud Banner, along with Hohhot New City and Duolun County, became one of the 100 National Pilot County related to using an egovernment platform to strengthen the openness and service of a county-level government. According to the requirements of the pilot program, the banner government carried out projects on the standardization and regulation of government affairs around land planning, demolition and resettlement, environmental protection, poverty alleviation and disaster relief, and employment and social security, and focused on establishing and fine-tuning a unified e-government platform and using that platform to fully and accurately publish government information about public affairs while standardizing the major administrative functions and convenience services. Being chosen to be part of the pilot program further promoted the construction of the egovernment platform in Ongniud Banner, strengthening its capacity to expose its decision-making, executive actions, management, and service process to the public. The banner government's official website included sections dedicated to "governmental information disclosure" and "government services". In 2012, the city's first electronic monitoring system was complete, and items related to administrative approval were synchronized with the banner government service center and the banner government portal website to allow the public to check the status of particular cases. The disclosure of government information since 2008 is shown in Fig. 1.

\section{Promote the upgrading of the quality of government service}

In 2014, the Administrative Service Center had the different administrative departments compile a list of government administrative powers, revealing the "power list" and inviting public supervision. The thirty-four administrative departments of

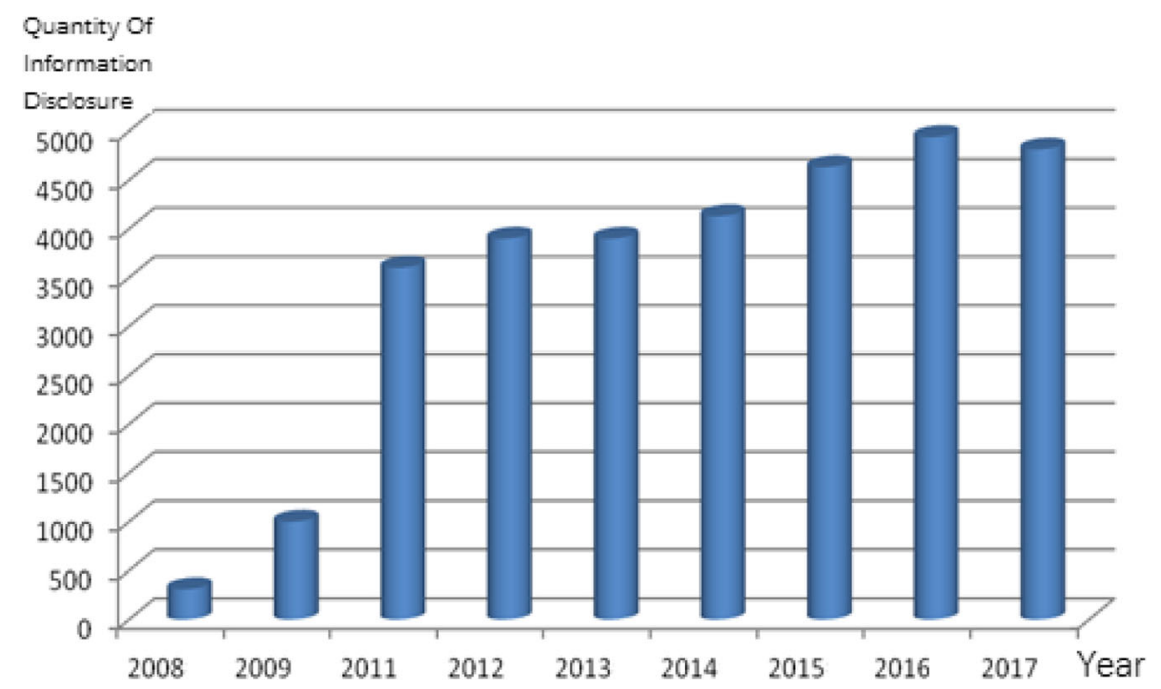

Fig. 1 Illustration of changes in government information disclosure during 2008-2017 
the whole banner announced 2356 administrative powers. The 191 items related to administrative inspection and approval for the whole banner were streamlined and 85 items were retained in the end. The reform of the services of the banner government has been further deepened by reducing the pre-approval requirement, leading in the implementation of the "business license first" reform, optimizing the approval process with innovative methods, simplifying the requirements and making reasonable approvals, and increasing transparency about government affairs. The disclosure of information by the government has been strengthened, and the official website is improving in its posting and update speeds, while highlighting the previous year's financial budget and final accounts as well as the "three public funds". They have also reduced fees, which has benefited the public by reducing the cost of the physical license.

Following the construction of and start of operations at the administrative inspection and approval service center in 2006, the number of completed cases and the number of total cases has changed greatly. The business environment of the whole banner has been greatly improved, and the activities of the various businesses are more convenient and orderly. After 2014, with the deepening of the party's policy on education practices, and the implementation of the inspection activities of Ongniud Banner and other related instructions by Premier Li Keqiang, the reform actions within the banner have improved in quality and efficiency, and the administrative center's case handling methodology and case volume has had a significant increase. The specific increase is shown in Fig. 2.

It can be seen from Fig. 2 that, following 2013, in addition to the continuous increase in the number of services, the case volume of the service center has also increased year by year. In 2016, the growth rate was even more impressive, laying a good foundation for the deepening of the fangguanfu reform.

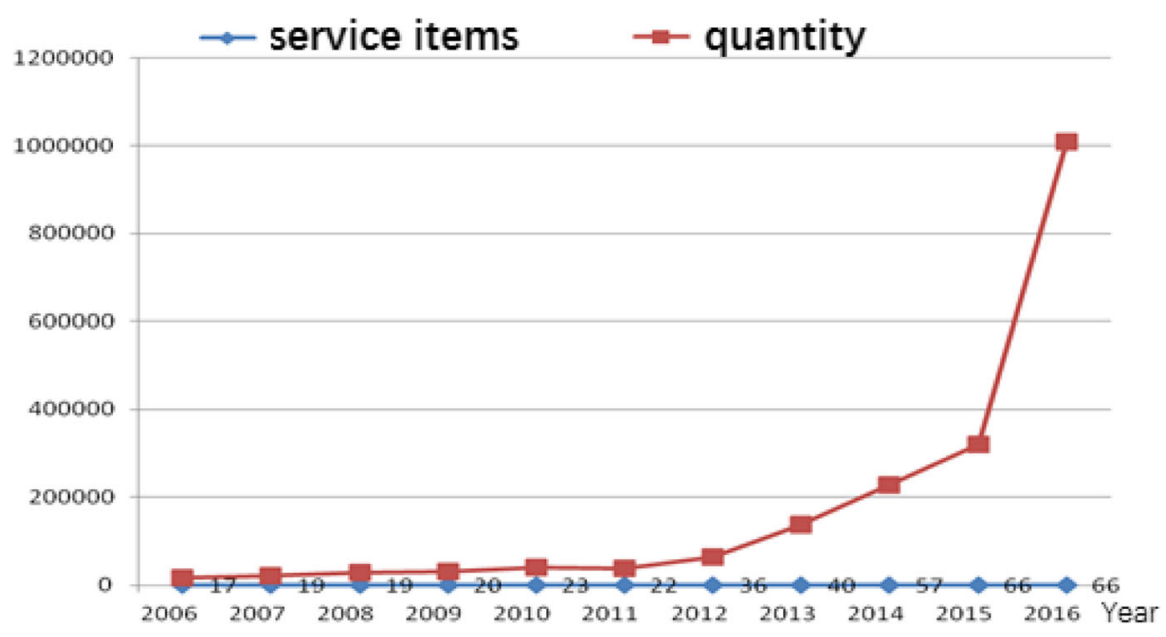

Fig. 2 Statistics on the handling of service items and quantity in the government service centers since 2006-2016 (items and quantity) 
Analysis of highlights of the Fangguanfu Reform

After the 18th National Congress of the Communist Party of China, Ongniud Banner actively implemented a series of decisions made between the Party Central Committee and its superiors, focusing on the problems reported by the public and private enterprise, such as the difficulty in finishing administrative affairs, the slow speed, the length of time involved, and the necessary physical exertion. The banner has promoted comprehensive reforms in the system for administrative inspection and approval as well as its style of work, and, along with the solid progress of the Fangguanfu Reform, has achieved remarkable results.

The establishment of the administrative approval service bureau will result in greater reform and higher service efficiency

Based on the reform of government affairs and the system of administrative inspection and approval during the past ten years, the spirit of the reform instructions under fangguanfu was actively implemented by Ongniud Banner. The original governmental service center was transferred to the sub-department unit of the Administrative Inspection and Approval Service Bureau. It became naturally linked with the inspection and approval bureau. The Administrative Service Center still retains the convenience service center, the business-related inspection and approval department, and the taxation service center. The inspection and approval process has achieved the goal of "only enter one door", "one trip maximum", "one window acceptance with parallel processing" and other such measures. The implementation has effectively improved the convenience for residents in handling matters involving business, taxation, or social affairs. Following the establishment of the Administrative Approval Service Bureau, the following measures were taken to achieve greater concentration of the inspection and approval authority and a greater improvement in service efficiency.

The approval items were further reduced and the four lists were more understandable The original 191 elements of administrative inspection and approval, such as cancellations, mergers and conversions, were reduced by 106 items with eighty-five items retained; twenty-four pre-approval items were revised, with five being retained, six being approved for back-end approval, seven being filed, and six being suspended. The number of approvals was reduced by eightyfour, along with a reduction by ten categories and thirty submissions of duplicate materials, and cancellation of nineteen requirements that were not legally supported or could be otherwise obtained.

Orderly transfer of approval rights The Administrative Approval Service Bureau and the original Administrative Inspection and Approval Department jointly signed the "Confirmation of the Transfer of Administrative Inspection and Approval Tasks". Eighty-four administrative inspection and approval tasks for seventeen departments-including the Development and Reform Bureau, the Education Bureau and the Civil Affairs Bureau-were transferred to the Administrative Approval 
Service Bureau at one time. The department's administrative inspection and approval authority was completely removed. After the completion of the transfer of the inspection and approval authority, the separation of inspection and approval from supervision was realized, and a county-level inspection and approval management system with consistent powers and responsibilities, a reasonable division of labor, scientific decision-making, smooth implementation and strong supervision was constructed.

The establishment of an efficient approval work team In order to ensure the efficiency of the inspection and approval service bureau, the staff are arranged and equipped under the principle of having a multi-functional office with multidisciplinary workers who prize pragmatism and efficiency, as well as fully considering factors such as case volume, age structure, and professional technical requirements, and thus select high-quality, capable personnel. The number of personnel has been reduced from 161 to forty-eight, a reduction of $70 \%$, and those in the eliminated positions have been transferred to the post-approval supervision and other fields.

The re-optimization of the approval process The approval process now has only two procedures: receiving and approving. Generally, the process only requires the approval of a leader of the business unit of the inspection and approval bureau, which significantly reduces the approval time. The approval process has been further optimized. All the inspection and approval requirements involved in the onsite inspection will be completed in the three steps of "acceptance, on-site inspection, and approval". Applications that do not require an on-site inspection can be done in the two steps of "acceptance and approval".

Information-sharing communication between approval and supervision The establishment of the Administrative Inspection and Approval Bureau has separated inspection and approval from supervision, and is the only way to deepen the reform of the system of administrative inspection and approval. In order to ensure a more smooth approval of administrative licensing rights, the banner government allowed the Administrative Approval Service Bureau and the various regulatory authorities to establish an interconnected information exchange and sharing platform.

The construction of a three-level service network has improved service capacity and pleased the public

In 2011, Ongniud Banner was established as one of one hundred pilot projects related to government services. The banner started a three-level network regarding convenience services between the banner, township, and village. In 2012, a convenience service center was built in seven towns with better conditions. There are 72 service tasks were transferred to the townships. In 2013, the banner increased its investment, totaling more than 5 million Chinese dollars in all, and it completed the construction of twelve convenience service centers, initially 
achieving a two-level connection between the banner and villages. In 2017, the banner established government service platform for the banner, township, administrative village and natural village. The banner has an administrative inspection and approval service center, thirteen townships have a convenience service center, 229 administrative villages have convenient service stations and 610 remote villages have group agency points. In the 118 administrative villages with internet, there are computers, cameras, ID card readers, high-speed photographic apparatus and other office equipment. The village-level convenience service stations have become Banner Government Service Center's remote window into the entire banner.

The approval system platform of the administrative inspection and approval bureau has been completed, relevant data has been entered, and a mobile application (APP) and a WeChat public account have been registered and opened. Residents can visit the website of the administrative inspection and approval bureau, the WeChat public account or the mobile app to obtain public and online consultations, online evaluations, online appointments, online applications, online pre-audits, video inspection, and inquiries.

Judging from the responses of the residents of Ongniud Banner, most cannot give satisfactory answers when asked about fangguanfu. People there seem generally unaware of the fangguanfu or lack a proper understanding of it. However, when asked whether the administrative service center has been convenient for them, most people will have very specific and vivid descriptions, especially those involved in business applications, based on the ease, the pleasant business environment, and the lack of fees. They have a very positive opinion of the government administrative services following the actions of the 18th National Congress. The questionnaire results gathered by the research team also show that the overall evaluation of the fangguanfu (streamline administration, delegate powers, and improve regulation service) contents is favorable, as the level of satisfaction is $86 \%$ (see Fig. 3), and the evaluation of the efficiency of the work is also quite positive (see Fig. 4).

\section{Main conclusions: the experience and enlightenment of the reform of Ongniud Banner}

In executing the higher-level decisions concerning administrative system reform, Ongniud Banner actively investigated and promoted the reforms based on the status of the banner, and the corresponding reforms reflect the principle of "simplicity, unity, and efficiency", optimized the productivity and lives of its people, and improved both the ability and quality of the services offered by the banner government. As a poverty-stricken and an economically underdeveloped county, the banner has clearly overcome more difficulties in achieving these results. For Ongniud Banner, the effectiveness of the fangguanfu reform is conducive to the formation of a good political ecology, the effective improvement of the relationship between the government and the public, and also the overall transformation of the social life of the banner domain. 


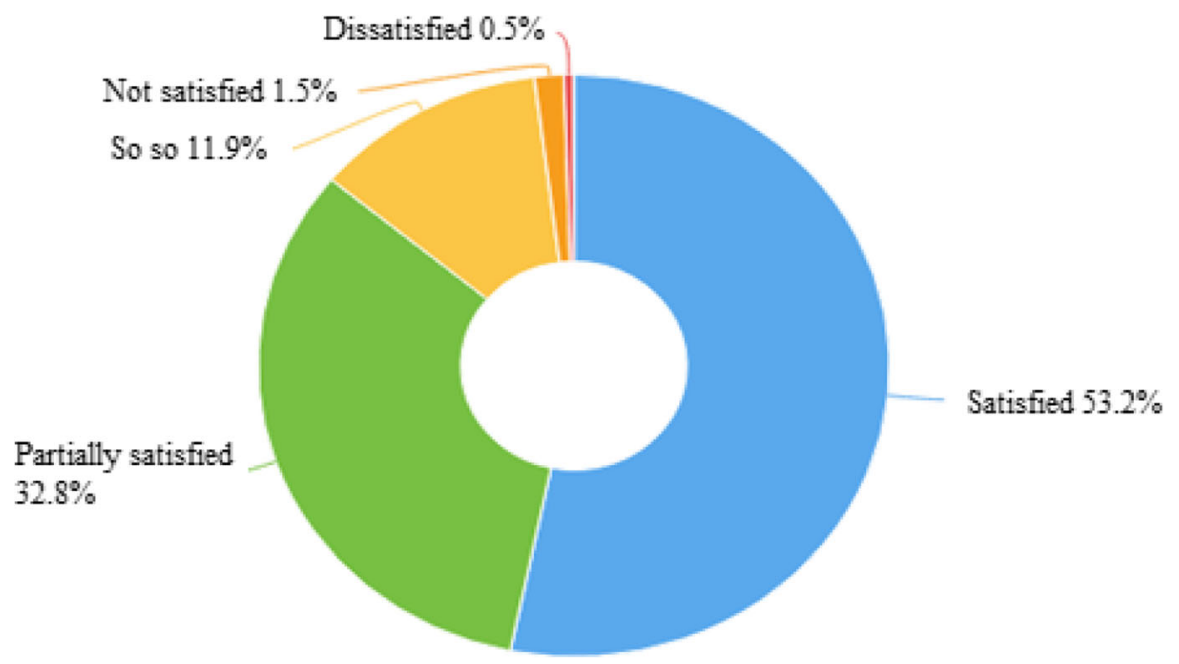

Fig. 3 The public's overall evaluation of the banner's fangguanfu

An empirical analysis of the reform of Ongniud Banner

In the Fangguanfu Reform within Ongniud Banner, the reality of the local situation was combined with the objectives of the Fangguanfu Reform to boldly investigate the reform, to draw on the experience from the first regions to develop, and to launch a number of measures, mostly in the ethnic areas, that were marked by local characteristics. In the case of impoverished areas, the combined impact of this investigation and practice tends to be typical.

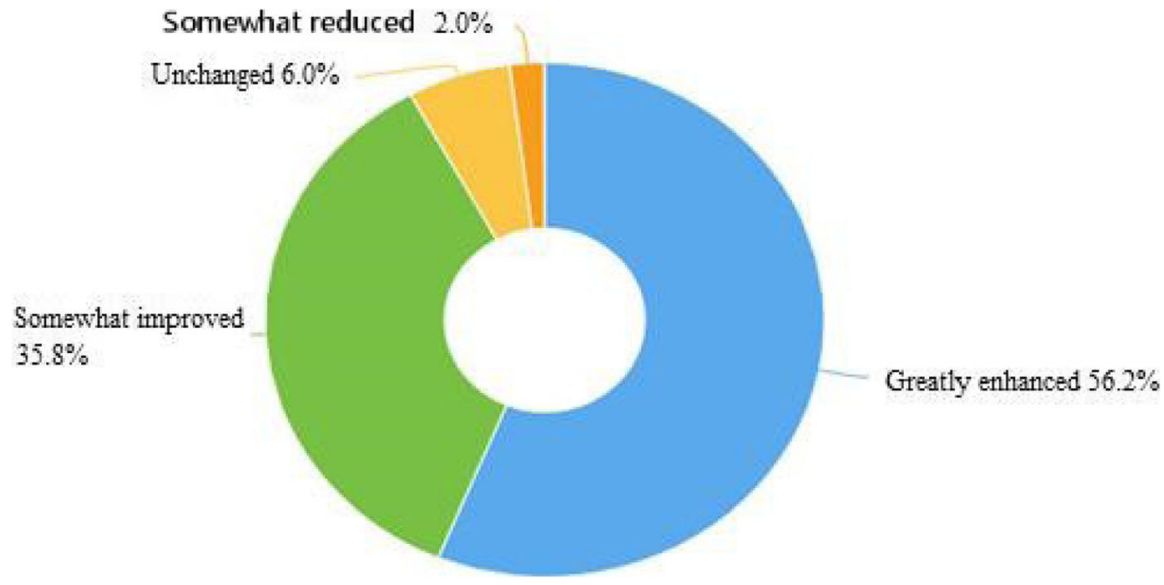

Fig. 4 Evaluation of the efficiency of the work of the public after the reform of the fangguanfu 


\section{Seize the opportunity to promote reform}

After 2000, the State Council's reforms related to government transparency and strengthening government services, pushing these driving force down to lower levels. In 2006, Ongniud Banner established an administrative service center, and the related government services were gradually enriched and facilitated. After the 18th National Congress of the Communist Party of China, the administrative system reforms centered on government transparency, government services, and the administrative inspection and approval reforms have been comprehensively promoted. Ongniud Banner fully utilized this forceful reform in the context of weak overall economic development and existing financial difficulties. It strived to obtain various pilot programs from higher levels, seizing these opportunities to promote reform. From 2015 to 2018, the Inner Mongolia autonomous region followed the action plan of the State Council's fangguanfu reform, and continuously advanced tasks and programs related to the work. Ongniud Banner followed the pace of reform set by the higher levels of government, aiming at improving its administrative efficiency, and broke through multiple bottlenecks. In 2017, the banner established the Banner Administrative Approval Service Bureau in order to provide an institutional guarantee for the Fangguanfu Reform.

\section{The main official is responsible, and the power is truly delegated}

Reforming the delegation of power promotes the transmission of driving force, and the pressure to reform moves down. The role of the county government is the key to this. With the policy direction determined, the party members are the key, and the banner chief must be committed to implementing fangguanfu. Because the delegation is real, it can achieve good results. In order to implement the decisions of their superiors about reform of aspects such as delegating power, promoting fangguanfu, and changing their status away from having "many obstacles", Ongniud Banner established the banner committee secretary to serve as the leader of the reform task force, and formed a task force with the banner chief and relevant department leaders from different levels of the banner as members with the intention of achieving the comprehensive deepening of the reform. The reform task force created an office, referred to as the "Banner Commission Reform Office", and promoted the delegation of power, which was led by a deputy chief of the banner. After three reorganizations in 2014, the initial goals of a simpler approval process a better business environment were achieved.

\section{The executives cooperate to advance}

The county-level fangguanfu reform is not a reform that involved all the members of the banner government. The chief officer was determined and good at making progress, and required the full mobilization and active cooperation of the core governmental bureaucracy. Based on interviews, prior to the establishment of the Approval Service Bureau as the government service center serving as the platform, in addition to the legal office, the editorial office or reform office, all the 
government agencies participated to carefully design and plan the reform, and their work was implemented in concrete ways. The aim of political decentralization and the promotion of departmental participation played an important role in the comprehensive reform movement through the whole banner. Judging from the interviews, the party members who specifically participated in the reform and promotion work have a clearer understanding of the significance and influence of the fangguanfu reform. They have a high ideological understanding, the ability to learn, and a strong work ethic. In addition to their responsibilities, they are motivated to find ways to overcome difficulties in their specific tasks and in tasks related to coordination. They all have a direct contribution to the performance of Ongniud Banner.

\section{Technological progress is strong, supportive, and promising}

The administrative scope of Ongniud Banner is expansive. Although transportation conditions have improved in recent years, the traditional methods of information transmission will still cause inconvenience to the residents. In 2012, in order for all administrative departments to join the administrative internet for the whole autonomous region, and so that the internet could assist in the finishing of more tasks to prevent the time-consuming and labor-intensive work for residents living in rural pastoral areas, the administrative department of Ongniud Banner constantly optimized its own internet functionality and expanded the "Internet + Convenience Service" model into the countryside. The functions of the two-level government service center in the towns were continuously strengthened, and the government service platform of the banner, township, and administrative village and natural village were built. This formed a convenient service network that was "horizontal to each side and vertical to the bottom", ensuring full coverage over the banner, townships, administrative villages, and the natural village service network. Now, the information transmission is fast and the efficiency of the work has greatly improved.

\section{Actively serve the main body of the market and innovate the way of supervision}

Compared with developed regions such as Jiangsu and Zhejiang, the businesses of Ongniud Banner are mostly small-scale operators who are concerned about the daily life of urban and rural residents, or the many small and micro-enterprises. The Administrative Service Center researches among these individual industrial and commercial households, responds to their questions, improves the approval process and timing, and establishes a specialized window at the economic agencies to provide a "green light" for the approval of the non-public economy. Further, the Administrative Center set up a full-service window to provide consultations for applicants, assist them in filling out various forms, and complete the acceptance after the initial examination. It also promoted a principle of full service windows and multi-functional offices. Each task is distributed by the system in an average way to everyone so that everyone can do every function which shortens the waiting time for approval. Ongniud Banner earnestly implemented the party's ethnic policy 
in conjunction with its ethnic language policy. In the government services provided to the residents, in the convenience service center of the eastern townships and villages, there are bilingual manuals, and guides, logos in Mongolian and Chinese, and bilingual workers on duty. Even from the early operations of the service center, special attention was paid to people with talents in the ethnic language and with bilingual talents so as to provide better services for local farmers and herdsmen.

Enlightenment from the reform of Ongniud Banner

In June 2017, Premier Li Keqiang pointed out: "The fangguanfu reform is a systematic whole. It is necessary to further improve the 'reduction' through delegation and decentralization of power, to create a 'tight-fitting suit' that slims power, while, at the same time, being good at the "addition" of stronger supervision and the 'multiplication' of the optimization service. The 'hard bones' concerning the transformation of government functions must be gnawed upon, so the goal of simpler approval, stronger supervision and better service can truly be achieved, which is indeed a difficult and complicated process." In this sense, Ongniud Banner is still facing many difficulties in the continuation of fangguanfu as it promotes the modernization of the government's administrative system. There is still a long journey before that goal is reached. There are two inspirations for the reform of the fangguanfu of Ongniud Banner:

The outstanding problems that need to be solved by the higher-level government: As the lower levels of government can be an example to those above them, the higher-level government should establish a government information communication system compatible with those used in the pilot program. After the pilot programs and policy explorations, Ongniud Banner, for example, has achieved admirable results by integrating its administrative resources through the establishment of the Administrative Approval Service Bureau. However, because the approval service bureau is a department of the autonomous region alone, in terms the vertical connection, the inspection and approval service bureau has no affiliation with the business departments above the city level, and the work is not well connected. In particular, it is impossible to directly and in a timely way obtain new policies related to administrative inspection and approval reform, or information and corresponding documents issued by municipal and municipal departments, including those related to personnel management and training issues. Yet it is necessary to establish a fault-tolerant reform mechanism for different levels of government as soon as possible, and broaden the reform of the fangguanfu. On May 20, 2018, the "Opinions on Further Encouraging the New Era of the Cadres in the New Era and Taking on New Actions" was reissued. The Party Central Committee promoted the exploration of a new goal related to the protection and motivation of the officers who are willing to do, dare to do, and able to do good and great works. The provincial party committee and the discipline inspection and supervision groups should take the lead in promulgating relevant standards, innovating working methods, quickly and accurately defining and correcting the mistakes that party members can easily make in the reform, and forming an 
effective fault-tolerant and error-correcting mechanism. This will provide support and regulation for those responsible for deepening the impact of the reform of "fangguanfu".

The outstanding problem that needs to be solved by the banner-level government: It is necessary to make full use of material and spiritual rewards, and to actually improve the treatment and benefit of approving personnel. In the process of forming the inspection and approval bureau, the relevant departments of the banner government have carefully selected twenty people to transfer to the Administrative Approval Service Bureau, according to the requirements of the leader to "choose the tough guy". In their original positions, the transferred personnel all had attained the title of "professional" based on the posting of relevant skill sets. After being transferred to the Administrative Approval Service Bureau, they were not appointed according to their original job title, a problem that needs to be resolved in time. Simultaneously, the work of the Administrative Approval Service Bureau is more demanding than similar tasks throughout the government, as the work time is not flexible, and the work intensity is high. There should be certain economic incentives to assist the people working at the windows to be more innovative and dynamic, and thereby to promote smoother work connections. A total of twenty-seven people were transferred from other departments to the Approval Service Bureau. In each business unit, four to five people oversee twenty approvals. The relevant approvals were highly professional, although the transferred personnel were all excellent and committed workers. They still need additional training to strengthen their professionalism in order to constantly adapt to new situations and be familiar with relevant business requirements. Additionally, it is necessary to improve the usage rate of convenience service stations in townships, convenience and service centers, and administrative villages, as well as expand services while promoting supervision. The individual regional leaders are not paying enough attention. The townships and towns have not yet formed a unified standard for their handling of particular situations. The individual village group agents are still unable to meet the needs of the public, either in direct service or through computer applications. These conditions need to be comprehensively upgraded.

\section{Short conclusion}

Ongniud Banner, in accomplishing the work set by the higher levels of changing its administrative systems, innovated new mechanisms and established specialized institutions that are adapted to this new environment and responsive to new social needs, in order to improve administrative efficiency so that it can more conveniently serve its people and enterprises. Ongniud Banner sincerely served the parties involved in the market. Through the transformation of government functions, the market will play a decisive role in the allocation of resources, and free the government for other roles, in order to develop a good economic and social environment as a result of these transformations. The achievements in fangguanfu reform, particularly on "fang" (delegation) and "fu" (service) are remarkable, while "guan" (supervision) needs further advancement. Therefore, as the banner party secretary, 
Nan Zhenhu, once said in making a solemn commitment at the meeting of comprehensive reform task force for the Inner Mongolia Autonomous Region Party Committee: "As the next step, we will increase our efforts to solve the problems of advancing the reforms-issues such as conservative and calcified thinking, and timid attitudes - to further actualize the fangguanfu reform. The scope of delegation must be greater, the management and supervision must be more flexible, and also the people we are serving must be more satisfied. We must embrace a temporary pain in exchange for the long-term benefits and welfare of the people."

Acknowledgements Not applicable.

\section{Authors' contributions}

Fang Yong conducts the whole investigation and designs the framework. JingHong Zhou shaochun zhang Wurigexletu Lei Shao and Xin Liang are responsible for the data collection, data cleaning and calculation. Six authors discussed together for the contents and wrote the whole manuscripts together. All authors read and approved the final manuscript.

\section{Funding}

Not applicable.

\section{Availability of data and materials}

Available from the author upon request.

\section{Ethics approval and consent to participate}

Not applicable.

\section{Consent for publication}

Not applicable.

\section{Competing interests}

I declare that I have no competing interests. 


\section{References}

The Office of the Coordination Group of the State Council for Promoting Reform and Transformation国务院 推进职能转变协调小组办公室, eds.: Fangguanfu - Reform Practices from Various Regions and Departments简政放权 放管结合 优化服务一一来自各地区各部门的改革实践, Beijing: People's Publishing House, 2017.

The third party evaluation project team of Qinghai Provincial Adminstration College, Third-Party Evaluation of 'Fangguanfu' in Qinghai Province 青海省“放管服”第三方评估研究, Beijing: National Academy of administration Press, January 2017.

Wei Xuanjun (魏旋君), ed.: Sanxiang Fangguanfu三湘放管服, Changsha: Hunan People's Publishing House, 2017.

\section{Publisher's Note}

Springer Nature remains neutral with regard to jurisdictional claims in published maps and institutional affiliations. 